\title{
PERTANGGUNGJAWABAN PIDANA BAGI PELAKU YANG MENYEBABKAN LUKA BERAT TERHADAP ORANG LAIN DALAM KECELAKAAN LALU LINTAS DI KOTA BATAM
}

\section{CRIMINAL OFFENDERS' RESPONSIBILITY CAUSING SERIOUS INJURIES TO TRAFFIC ACCIDENTS VICTIM IN BATAM}

\author{
Rustam \\ Fakultas Hu ku m Universitas Riau Kepulauan \\ Batam, Indonesia \\ fendy_harjo@yahoo.com
}

\begin{abstract}
Abstrak
Tujuan penelitian ini adalah untuk mengetahui pertanggungjawaban dari pelaku kecelakaan yang menyebabkan luka berat dalam kecelakaan lalu lintas di kota batam. Faktor- faktor apa yang menjadi pert imbangan Hakim dalam perkara nomor: 169/pid. B/ 2014/PN. Batam.Pada pengadilan Negeri Batam. Penelit ian ini menggunakan metode penelitian yuridis normative dan menggunakan data sekunder yaitu data yang diperoleh dari bahanbahan, pustaka berupa putusan pada penngadilan dan peraturan Perundang - undangan yang berlaku serta bukubuku (literatur) dan karangan- karangan ilmiah, artikel dan tulisan ilmiah $\mathrm{Hu}$ ku m yang terkait dengan objek penelitian. Hasil penelitian ini adalah terdakwa dalam melaku kan tindak pidana karena kelalaianya menyebabkan kecelakaan lalu lintas dengan korban luka berat. Maka pert imbangan Hakim adalah melihat terdakwa melarikan diri dan tidak menolong korban pada saat kejadian.
\end{abstract}

Kata kunci: Pertanggungjawaban Pidana dan Putusan Hakim.

\section{Abstract}

The purpose of this study was to determine the offenders' responsibility causing serious injuries to traffic accidents in Batam City. Considerable factors of Judge for case number: 169/pid. B/2014/PN Batam at Batam court. This research used normative juridical research and using obtained data field and court judgments libraries, law regulations, books and scientific articles and scientific papers related to the object of research were as secondary data. The result of this research showed that the defendant in committing a criminal act due to his negligence causing traffic accidents with serious injury victim. So the judge's consideration was the defendant's escape and did not give a help to the victim at the time.

Keywords: Criminal Responsibility and Judge's Decision. 


\section{PENDAHULUAN}

Menyadari laju perkembangan teknologi modern yang diikuti pula laju perkembangan penduduk yang kian padat, maka hal ini dapat menimbulkan permasalahan-permasalahan di berbagai bidang, salah satunya adalah bidang lalu lintas jalan raya.

Perkembangan lalu lintas modern di satu pihak akan memberikan kemudahankemudahan pemakaian jalan untuk kegiatan sehari- hari dalam rangka pekerjaannya, kehidupannya dan lain- lainnya. Namun di pihak lain akan membawa akibat-akibat permasalahan yang komplek antara lain meningkatnya pelanggaran-pelanggaran, kemacetan lalu lintas, dan kriminalitas yang berkaitan dengan lalu lintas.

Di segi sosial seperti pertambahan penduduk, dan di segi ekonomi seperti kenaikan taraf hidup rakyat, memungkinkan rakyat mampu untuk memiliki kendaraan-kendaraan bermotor pribadi. Pertambahan jumlah kendaraan bermotor yang tidak seimbang dengan ketersedian sarana dan prasarana serta peralatan lalu lintas, seperti jalan raya, akan membawa akibat peningkatan mobilitas manusia. Hal ini dapat menimbulkan peningkatan frekuensi dan volume lalu lintas di jalan raya. Selain itu, disiplin dan kesadaran Hukum masyarakat pemakai jalan yang masih belum dapat dikatakan baik, belum memiliki kepatuhan, ketaatan untuk mengikuti hukum yang berlaku juga diasumsikan menjadi faktor yang menyebabkan banyaknya terjadi kecelakaan di jalan raya.

Tingkat kesadaran Hukum masyarakat sebagai pemakai jalan dapat diukur dari kemampuan dan daya serap individu, serta bagaimana penerapannya di jalan raya. Manusia sebagai pemakai jalan sangat menentukan terjadinya pelanggaran-pelanggaran lalu lintas yang menimbulkan kecelakaan lalu lintas. Pasal 1 angka 24 UU No. 22 Tahun 2009 Tentang Lalu Lintas dan Angkutan Jalan menyebutkan bahwa : "Kecelakaan Lalu lintas adalah suatu peristiwa di jalan yang tidak diduga dan tidak disengaja melibatkan kendaraan dengan atau tanpa pengguna jalan lain yang mengakibatkan korban manusia dan/atau kerugian harta benda."

Ditambahkan pula oleh Naning $(1983$; 23) bahwa, "Faktor- faktor penyebab terjadinya kecelakaan adalah faktor manusia sebagai pemakai jalan (faktor utama), faktor kendaraan, faktor jalan, dan faktor keadaan atau alam”.Maka dari itu pemerintah, da lam hal ini petugas hukum terutama pihak kepolisian, khususnya polisi lalu lintas, telah melakukan berbagai upaya, baik yang bersifat preventif maupun represif, untuk mencegah atau mengurangi terjadinya pelanggaran lalu lintas yang menimbulkan kecelakaan lalu lintas di jalan..

Dalam alinea ke4 Pembukaan Undang - Undang Dasar 1945 tercantum tujuan pembangunan Nasional Negara Indonesia yaitu: Melindungi segenap Bangsa Indonesia, 
Me majukan kesejahteraan umum, Mencerdaskan kehidupan bangsa, Ikut melaksanakan ketertiban dunia yang berdasarkan kemerdekaan, perdamaian abadi dan keadilan sosial.

Tujuan tersebut dapat dicapai melalui upaya pembangunan nasional dalam segala

bidang kehidupan bangsa, termasuk di dalamnya bidang hukum yang dilakukan secara berkelanjutan. Pembangunan di bidang hukum diarahkan pada makin nyatanya pelaksanaan sys te $\mathrm{m}$ hokum nasional Indonesia agar tercipta kehidupan masyarakat yang adil dan makmur berdasarkan Pancasila dan Undang - Undang Dasar 1945.

Untuk mencapai tujuan pembangunan nasional sebagai pengamalan Pancasila dan Undang-Undang Dasar 1945, sangat diperlukan sarana perhubungan ,baik dalam arti transportasi, maupun komunikasi dan juga teknologi penunjangnya. Hal ini harus tercermin pada kebutuhan mobilitas seluruh sector dan wilayah yang memiliki arti penting dan strategis dalam pembangunan bangsa, khususnya dalam penataan di sector tranportasi atau penataan lalu lintas.

Wilayah Negara kesatuan Republik Indonesia yang begitu luas yang membentang dari Sabang sampai Merauke sangat diperlukan adanya penataan sector transportasi yang tepat dan berdaya guna serta berhasil guna. Untuk itu diperlukan suatu sumber daya manusia yang dapat menunjang terciptanya tatanan maupun pranata Hukum yang tepat, khususya Hukum lalu lintas guna mewujudkan pembangunan Nasional seperti yang sudah digariskan di dalam Pembukaan Undang Undang Dasar 1945.

Adapun macam alat transportasi yang digunakan untuk mengadakan hubungan antar wilayah ada tiga jenis yaitu alat transportasi darat, alat transportasi laut, dan alat transportasi udara (Undang-Undang No 22 Tahun 2009). Salah satu subsec tor yang penting dan yang menonjol dalam pembangunan dewasa ini adalah sector transportasi darat, khususnya adalah lalu lintas jalan raya. Hal ini disebabkan karena sebagian besar arus perhubungan menggunakan prasarana jalan. Oleh sebab itu maka dapat dikatakan bahwa lalu lintas jalan raya mempunyai arti penting bagi perkembangan masyarakat. Dalam hal ini timbul suatu masalah mengenai bagaimana dapat dijamin lalu lintas yang aman, tertib, lancar, dan efisien guna menjamin kelancaran berbagai aktifitas untuk menciptakan kemakmuran dan ketentraman masyarakat.

Me lalui ketertiban berlalu lintas yang apabila menunjukkan adanya tertib lalu lintas berarti masyarakatnya berdisiplin atau sebaliknya tidak tertibnya lalu lintas yang terlihat, maka dapat dipastikan bahwa disiplin masyarakat di semua bidang usaha amburadul. Penyelenggaraan sector transportasi tersebut perlu diselenggarakan secara berkelanjutan dan terus ditingkatkan agar luas daya jangkau dan pelayanan kepada 
masyarakat dapat terlayani dengan sebaik-baiknya, kelestarian lingkungan dapat terpelihara dan terjaga. Hal ini diperlukan adanya suatu koordinasi antara pemerintah pusat dan pemerintah daerah, tentunya peran serta seluruh lapisan masyarakat sangat menentukan terciptanya sistem transportasi nasional yang handal dan terpadu.

Pembangunan sarana dan prasarana transportasi berupa jalan agaknya selalu tertinggal dengan laju pertambahan armada transportasi yang meningkat secara pesat. Hal ini sering kita jumpai di kota besar, khususnya jalan jalan utama atau jalan raya yang hamper setiap hari macet. Bukan itu saja penyebab utama dari kemacetan itu juga tidak terlepas dari lemahnya tingkat disiplin dan kepatuhan para pemakai jalan terhadap peraturan peraturan lalu lintas yang ada dan banyak terdapat di jalan - jalan khususnya di kota besar.

Kecelakaan lalu lintas menjadi bukti lemahnya tingkat disiplin dan kepatuhan para pemakai jalan terhadap tata tertib dan peraturan lalu lintas yang ada di jalan. Walupun ada factor lain selain factor manusia, seperti faktor kendaraan (sarana), factor jalan (prasarana) dan factor lingkungan (alam). Di antara faktor factor tersebut, factor manusia merupakan factor yang paling menentukan terjadinya kecelakaan lalu lintas, sebab kelemahan kelemahan yang timbul dari faktor faktor lain dapat diatasi apabila pengemudi berlaku hati hati, taat pada peraturan lalu lintas dan memperhatikan serta menyiapkan kendaraan sebelum berangkat, demikian pula dalam menjalankan kendaraannya diperlukan untuk berhati-hati untuk mencegah terjadinya kecelakaan lalu lintas.

Sasaran pembinaan'D is iplin berlalu lintas'tidak hanya ditunjukkan kepada manusia sebagai pengguna jalan, tetapi juga harus ditujukan pada jumlah kendaraan, sarana serta prasarana lalu lintas, dan penga wasan instansi terkait. Pasaribu mengatakan dalam Paladeng, $(1993 ; 24)$ bahwa keseimbangan antara hak dan kewajiban dari segenap lapisan masyarakat jalan, pada pokoknya bertujuan untuk melindungi masyarakat umum. Dia prihatin terhadap adanya berita diluar negeri yang menyebutkan bahwa jalan jalan raya di Indonesia merupakan arena pembantaian terhadap nyawa manusia.

Dalam hal ini Pemerintah melalui kebijakannya mengeluarkan seperangkat aturan dan peraturan guna menanggulangi kecelakaan lalu lintas yang dapat mengakibatkan jatuhnya korban jiwa yang disebabkan karena kelalaian si pengemudi di jalan. Salah satu ketentuan hokum yang dapat dikenakan terhadap pengemudi atau pelaku dalam perkara kecelakaan lalu lintas adalah Pasal 310 (3) Undang Undang Nomor 22 Tahun 2009 yang berbunyi:suatu perbuatan yang mengakibatkan luka berat terhadap orang lain dengan pidana penjara 5 tahun dan denda 5.000.000,00. Pertanggungja waban pidana terhadap pengemudi yang mengakibatkan matinya orang lain karena kealpaannya dalam peristiwa kecelakaan lalu lintas 
tersebut harus dapat dibuktikan adanya kesalahan.

\section{METODOLOGI}

Penelitian ini menggunakan metode yuridis normatif, dengan sumber data terdiri dari dua macam, yakni data primer dan data sekunder. Data primer dalam penelitian ini adalah putusan yang diperoleh ari Pengadilan Negeri Batam, sedangakn data sekunder peneliti dapatkan dari bahan hukum primer, sekunde dan bahan hukum tersier. Data primer yang telah didapatkan peneliti, dianalisa dengan menggunakan norma dan kaidah hukum yang ada, serta pendapat para pakar dan ahli yang didapatkan dari bahan kepustakaan yang ada.

\section{PEMBAHASAN}

Sebagai sebuah Negara yang berdasarkan Hukum, Indonesia memiliki tujuan untuk mewujudkan masyarakat adil dan makmur yang merdeka, bersatu, dan berdaulat berdasarkan Pancasila dan Undang Undang Dasar Negara Republik Indonesia Tahun 1945. Pemaknaan konsep Negara hukum berdasarkan pancasila menurut syachran didasarkan pada analisis penyelenggaraan fungsi dan tugas pemerintahan,dimana terdapat suatu jaminan bahwa tindakan tindakan Negara tidak melanggar hak dan kewajiban asasi manusia,serta adanya suatu keseimbangan antara kepentingan Negara yang mewakili kepentingan umum dan kepentingan rakyat (perorangan),sehingga apabila terjadi sengketa antara pemerintah dengan rakyat,masyarakat dengan masyarakat,individu dengan individu, terdapat suatu jamina $n$ pengayoman hukum berdasarkan pancasila,yang pada sila pertamanya telah menyebutkan"Ketuhanan Yang Maha Esa" (Basah, 1997; 3)

Peranan Hukum dalam pembangunan adalah untuk menjamin bahwa perubahan terjadi dengan teratur. Perubahan teratur demikian dapat dibantu oleh perundang-undangan atau keputusan pengadilan atau kombinasi dari kedua-duanya.Perubahan yang teratur melalui prosedur Hukum,baik ia berwujud Perundang undangan atau keputusan badan badan peradilan lebih baik daripada perubahan yang tidak teratur dengan menggunakan kekerasan semata- mata sebagaimana telah didefinisikan oleh mochtar kusumaatmaja,bahwa Hukum merupakan keseluruhan asas-asas dan kaidah kaidah yang mengatur kehidupan manusia dalam masyarakat yang meliputi lembaga lembaga dan proses-proses yang mewujudkan berlakunya kaidah kaidah itu dalam kenyataan.

Keberadaan Hukum dalam gerak pembangunan suatu bangsa menurut Kusumaatmaja (20016;

3), berdasarkan teori hukum pembangunan disampaikan bahwa hukum merupakan suatu alat untuuk memelihara ketertiban dalam masyarakat. Mengingat fungsinya sifat 5 
hukum, pada dasarnyaa adalah konservatif artinya, hukum bersifat memelihara dan mempertahankan yang telah tercapai. Fungsi demikian diperlukan dalam setiap masyarakat, termasuk masyarakat yang sedang membangun, karena disini pun ada hasil hasil yang harus dipelihara dilindungi dan diamankan. Akan tetapi, masyarakat yang sedang berubah cepat,hukum tidak cukup memiliki fungsi demikian saja. Ia juga harus dapat membantu proses perubahan masyarakat itu. Untuk itu, proses dan kegiatan penegakan Hukum harus mencakup pula segala aktivitas yang dimaksudkan agar hukum sebagai perangkat kaedah normatif yang mengatur dan mengikat para subjek Hukum dalam segala kehidupan bermasyarakat daan bernegara benar benar ditaati dan sungguh sungguh dijalankan sebagaimana mestinya.

\section{Teori- Teori Pe midanaan}

Dalam masalah pemberian pidana perlu diketahui tentang teori-teori pemidanaan. Ada tiga golongan utama teori-teori pemidanaan untuk membenarkan penjatuhan pidanayaitu:

1)Teori Absolut

Menurut teori ini pidana dijatuhkan semata-mata karena orang telah melakukan suatu kejahatan atau tindak pidana (Poernomo, 1993; 174) P idana merupakan akibat mutlak yang harus ada sebagai suatu pembalasan kepada orang yang melakukan kejahatan. Jadi dasar pembenaran dari pidana terletak pada ada atau terjadinya kejahatan itu sendiri.

2)Teori Relatif

Menurut teori ini memidana bukanlah untuk memuaskan tuntutan dari keadilan. Pembalasan itu sendiri tidak mempunyai nilai, tetapi hanya sebagai sarana untuk melindungi kepentingan masyarakat. Oleh karena itu teori ini pun sering disebut teori tujuan. Pidana dijatuhkan bukan karena orang membuat kejahatan, melainkan supaya orang jangan melakukan kejahatan. Tujuan pidana untuk mencegah kejahatan ini biasa dibedakan antara istilah prevensi special dan prevenasi general atau sering juga dipergunakan istilah spe c $i$ al deternce dan general deterence. Dengan prevensi special dimaksudkan pengaruh pidana terhadap terpidana.

Jadi pencegahan kejahatan itu ingin dicapai pidana dengan mempengaruhi tingkah laku si terpidana untuk tidak melakukan tindak pidana lagi. Ini berarti pidana bertujuan agar si terpidana itu berubah menjadi baik dan berguna bagi masyarakat dan negara. Teori tujuan pidana serupa ini dikenal dengan sebutan teori reformasi atau rehabilitation. Dengan prevensi general dimaksudkan memberi 
dampak pengaruh pidana terhadap masyarakat umumnya. Arti pencegahan itu ingin dicapai oleh pidana dengan mempengaruhi tingkah laku anggota masyarakat pada umumnya untuk tidak melakukan tindak pidana (Moeljatno, , 2000; 137)

3)Teori Gabungan

Teori gabungan ini timbul karena adanya keberatan keberatan terhadap teori pembalasan dan teori tujuan, yang menyatakan bahwa pidana hendaknya didasarkan atas tujuan unsur-unsur pembalasan dan mempertahankan ketertiban masyarakat, yang diterapkan secara kombinasi dengan menitik beratkan pada salah satu unsurnya tanpa menghilangkan unsure yang lain, mau pun pada semua unsure yang ada.

Di samping pembagian secaratradisional teori teori pemidanaan seperti dikemukakan di atas, yakni teori absolute dan teori relatif, adateori yang disebut teori gabungan (verenigings theorisen). Menurut Rossi pada teori gabungan ini, ia menganggap bahwa pembalasan sebagai suatu asas dari pidana dan bahwa beratnya pidana tidak boleh melampaui suatu pembalasan yang adil, namun dia berpendirian bahwa pidana mempunyai berbagai pengaruh antara lain perbaikan sesuatu yang rusak dalam masyarakat dan prevensi general. Ada pula pengelompokan pengertian mengenai tujuan pidana menjadi dua kelompok yaitu aliran klasik dan aliran modern.

Pada aliran klasik dipengaruhi paham indeterminis me yaitu suatu paham yang menganggap bahwa manusia mempunyai kehendak bebas (free will) dalam melakukan tindakannya. Menurut aliran klasik pidana ditentukan secara pasti (definite sentence). Sedangkan aliran modern dipengaruhi paham determinis me yaitu suatu paham yang menganggap bahwa manusia tidak mempunyai kebebasan dalam melakukan tindakannya.

Menurut Soedarto: Aliran klasik melihat terutama pada perbuatan yang dilakukan dan menghendaki pidana yang dijatuhkan itu seimbang dengan perbuatan tersebut, sedangkan aliran modern pertama-tama meninjau perbuatannya dengan menghendaki individualisasi dari pidana, artinya dalam pemidanaan memperhatikan sifat-sifat dan keadaan si pembuat secara ekstrim dapat dikatakan bahwa aliran dalam pemberian pidana lebih melihat kebelakang."

Penerapan Pasal 310 (3) U U R I N o m o r 22 T a h u n 2009 terhadap Pengem udi Yang Menyebabkan Luka Berat Terhadap Orang Lain Dalam Kasus Kecelakaan Lalu lintas Oleh Hakim Pengadilan Negeri Batam. Suatu putusan Hakim dalam kasus kecelakaan lalu lintas sering kali menimbulkan reaksi yang kontroversial, sebab keadilan yang dirasakan masyarakat sering kali tidak sesuai dengan apa yang diharapkan. Hal ini tergantung dari sisi mana masyarakat memandangnya, dipandang dari sis i pelaku dirasakan 
putusan Hakim teramat berat, sebalikny akalau dipandang dari sisi keluarga korban dirasakan terlalu ringan.

Penerapan Pasal 310 (3) UU RI Nomor 22 Tahun 2009 Pasal dalam kasus kecelakaan lalu lintas sangat bervariatif, hal ini dikarenakan tiap- tiap pelaku memiliki tingkat kesalahan yang berbeda, sehingga Majelis Hakim dalam menjatuhkan suatu putusan terhadap pelaku tindak pidana menggunakan berbagai pertimbangan dari berbagai unsur. Pasal 310 (3) UU Nomor 22 Tahun 2009 “Tentang Lalu litas dan Angkutan jalan”. Hal ini menandakan bahwa kealpaan juga merupakan suatu kesalahan yang menjadi dasar untuk menjatuhkan pidana kepada seseorang.

Dalam penelitian ini, penulis memberikan contoh perkara kelalaian yang menyebabkan luka berat terhadap orang lain, sehingga bagaimana penerapan Pasal 310 (3) UU Nomor 22 Tahun 2009 bagi seseorang yang menyebabkan luka berat terhadap orang lain pada kecelakaan lalu lintas oleh Hakim PengadilanNegeri Bata m.

- Menyatakan terdakwa OKI AZHARI bersalah melakukan tindak pidana Karena Kelalalannya mengakibatkan kecelakaan laiu lintas dengan korban luka berat. Sebagaimana dalam Dakwaan Pasal 310 (3) Undang- Undang RI Nomor 22 Tahun 2009 tentang Lalu Lintas dan Angkutan Jalan.

- Menjatuhkan pidana terhadap terdakwa OKI AZHARI dengan pidana penjara selama 1 (satu) 4 (empat) bulan dikurangi selama terdakwa berada dalam tahanan, dengan perintah terdakwa tetap ditahan.

- Menjatuhkan kepada terdakwa pidana denda sebesar Rp. 5.000.000,- (lima Juta rupiah) dengan ketentuan apabila denda tersebut tidak dibayar diganti dengan kurungan selama 3 (tlga) bulan.

Lalu lintas berarti berbicara mengenai manusia, kendaraan, dan jalan yang masingmasing mempunyai masalah tersendiri dan berkaitan dengan keselamatan hidup orang banyak khususnya para pemakai jalan raya. Dalam kamus Umum Bahasa Indonesia, lalu lintas diartikan sebagai : "Berjalan bolak-balik, hilir mudik, perihal perjalanan di jalan dan sebagainya, perhubungan antara sebuah tempat dengan tempat lain"Poerwadarmita, 1996; 500.Sementara Djajusman (1976: 8) dalam bukunya, "Polisi dan Lalu Lintas", mengartikan lalu lintas sebagai : "Gerak- gerik pindah manusia dengan atau tanpa alat penggerak dari satu tempat ke tempat lain".Sementara UU No. 14 Tahun 1992 Tentang Lalu Lintas Dan Angkutan Jalan, memberikan pengertian lalu lintas sebagai gerak kendaraan, orang, dan hewan di jalan. Sedangkan jalan diartikan sebagai jalan yang diperuntukan bagi lalu lintas 
umum, dan kendaraan adalah alat yang dapat bergerak di jalan, terdiri dari kendaraan bermotor dan kendaraan tidak bermotor.

Dalam Pasal 1 angka 2 UU No. 22 Tahun 2009 Tentang Lalu Lintas Dan Angkutan Jalan mengartikan lalu lintas dengan gerak kendaraan dan orang di ruang lalu lintas jalan. Sementara itu, jalan diartikan dalam Pasal 1 angka 12 dengan seluruh bagian jalan, termasuk bangunan pelengkap dan perlengkapannya yang diperuntukan bagi lalu lintas umum, yang berada pada permukaan tanah, di atas permukaan tanah, di bawah permukaan tanah dan/atau air, serta di atas permukaan air, kecuali jalan rel dan jalan kabel.

Sehubungan dengan pengertian pelanggaran lalu lintas, tidak dijumpai dalam UU lalu lintas baik dalam UU No. 14 Tahun 1992 Tentang Lalu Lintas Dan Angkutan Jalan dan dalam UU No. 22 Tahun 2009 Tentang Lalu Lintas Dan Angkutan Jalan maupun dalam KUHP. Dalam KUHP dikenal adanya pelanggaran akan tetapi tidak dijelaskan apa yang dimaksud dengan pelanggaran itu sendiri kecuali hanya menempatkannya dalam buku ketiga KUHP. Dalam UU lalu lintas yang lama yaitu UU No. 14 Tahun 1992 Tentang Tentang Lalu Lintas Dan Angkutan Jalan juga tidak dijumpai pengertian pelanggaran tersebut. Kata-kata pelanggaran hanya dijumpai dalam salah satu pasalnya, yaitu Pasal 68 yang berbunyi sebagai berikut : “Tindak Pidana sebagaimana dimaksud dalam pasal 54, Pasal 55, Pasal 56, Pasal 57, Pasal 58, Pasal 59, Pasal 60, Pasal 61a, Pasal 62, Pasal 63, Pasal 64, Pasal 65, Pasal 66, dan Pasal 67 adalah pelanggaran".

Dalam UU No. 22 Tahun 2008 Tentang Lalu Lintas Dan Angkutan Jalan juga tidak ditemui pengertian pelanggaran akan tetapi kata-kata pelanggaran tersebut ditemui dalam Pasal 316 ayat (1) yang berbunyi sebagai berikut :

“Ketentuan sebagaimana dimaksud dalam Pasal 274, Pasal 275 ayat (1), Pasal 276, Pasal 278, Pasal 279, Pasal 280, Pasal 281, Pasal 282, Pasal 283, Pasal 284, Pasal 285, Pasal 286, Pasal 287, Pasal 288, Pasal 289, Pasal 290, Pasal 291, Pasal 292, Pasal 293, Pasal 294, Pasal 295, Pasal 296, Pasal 297, Pasal 298, Pasal 299, Pasal 300, Pasal 301, Pasal 302, Pasal 303, Pasal 304, Pasal 305, Pasal 306, Pasal 307, Pasal 308, Pasal 309, dan Pasal 313 adalah Pelanggaran."

Berdasarkan materi Pasal 68 UU No. 14 Tahun 1992 dan UU No. 22 Tahun 2009 Tentang Lalu Lintas Dan Angkutan Jalan di atas, dapat dikatakan bahwa yang dimaksud dengan pelanggaran adalah pelanggaran terhadap keharusan dan ketentuan dalam pasal-pasal yang ditentukan oleh undang- undang tersebut. Dengan demikian, dapat pula dikemukakan bahwa yang dimaksud dengan pelanggaran lalu lintas yaitu pelanggaran terhadap peraturanperaturan khusus tentang lalu lintas yang terdapat dalam UU No. 22 Tahun 2009 Tentang 
Lalu Lintas Dan Angkutan Jalan atau dengan kata lain pelanggaran lalu lintas adalah pelanggaran terhadap peraturan-peraturan khusus tentang lalu lintas, yang berisi keharusan dan ketentuan seperti yang tercantum dalam pasal-pasal yang ditunjuk oleh pasal 316 ayat (1) UU No. 22 Tahun 2008 Tentang Lalu Lintas Dan Angkutan Jalan.

Penanggulangan Pelanggaran Lalu lintas, efektifnya perjalanan Undang-Undang Nomor 22 Tahun 2009 Tentang Lalu Lintas Dan Angkutan Jalan tidak terlepas dari dukungan kerjasama secara terpadu dan berkelanjutan semua lapisan masyarakat dan aparat penegak hukum. Caranya mematuhi segala peraturan yang ada dalam Undang- Undang tersebut. Sehingga apa yang diinginkan oleh masyarakat dapat tercapai dengan baik dan sebaliknya baik pelanggaran maupun kecelakaan yang terjadi di jalan raya dapat diminimalisir setiap saat.Penanggulangan kejahatan dapat dilakukan dengan dua cara, yaitu :

1. Penanggulangan Dengan Cara Moralistik

Penanggulangan dengan cara moralistik adalah usaha- usaha yang dilakukan dalam mencegah pelanggaran lalu lintas melalui usaha- usaha pembinaan, memperkuat moral dan mental agar kebal terhadap bujukan, godaan atau sesuatu yang buruk yang dapat mempengaruhi bagi pemakai kendaraan. Langkah- langkah konkrit yang dilakukan melalui cara moralistik yakni

a. Pembinaan terhadap kesadaran mental terdiri dari :

- Mendorong dan membina seseorang agar mereka sadar dan mau menjalankan semua peraturan perundang-undangan yang berlaku dengan cara yang baik.

- Membina seseorang agar dapat ikut serta dalam berbagai kegiatan terutama dalam hal penyuluhan hukum.

- Aparat hukum selalu memberikan petunjuk teknis terutama kepada masyarakat yang kurang memahami isi dari undang-undang lalu lintas.

b. Penanggulangan Dengan Cara Abalisionistik

Penanggulangan dengan cara abalisionistik adalah menghilangkan atau memperkecil sebab-sebab terjadinya pelanggaran maupun kecelakaan dalam berlalu lintas di jalan raya melalui upaya selalu memberikan tindakan nyata kepada para pemakai kendaraan apabila tidak memakai helm, SIM(Surat Izin Mengemudi, STNK(Surat Tanda Nomor Kendaraan), dan BPKB(Buku Pemilik Kendaraan Bermotor) dari kendaraan yang dibawanya dengan cara diproses menurut hukum yang berlaku tanpa adanya perbedaan diantara pelaku itu sendiri. Sebagaimana yang terdapat pada Pasal 200 UU. No. 22 Tahun 2009 tentang Lalu Lintas Angkutan Jalan, tugas kepolisian yang paling sering dijumpai di lapangan dalam penertiban 
pelanggaran lalu lintas yang berpotensi menyebabkan kecelakaan lalu lintas di antaranya:

a) Memberikan penerangan terhadap pemakai jalan, baik terhadap pejalan kaki maupun pemakai dengan kendaraan di jalan raya.

b) Memberikan penerangan terhadap pemohon surat izin mengemudi (SIM) di ruang teori tempat pembuatan SIM.

c) Mengadakan patroli lalu lintas di jalan yang dianggap padat arus lalu lintas.

d) Melakukan pencegahan bersama terhadap segala problematika berlalu lintas.

e) Mengatur pejalan kaki maupun pengemudi kendaraan dalam berlalu lintas.

Sementara kewajiban dari pihak yang berwajib dalam menanggulangi tindak pidana pelanggaran lalu lintas di jalan raya adalah mewajibkan bagi pengendara kendaraan yang ditilang untuk dapat menghadap sendiri dalam sidang pengadilan dan menghukum pelaku pelanggaran lalu lintas dengan hukuman yang setimpal. Tindakan ini dilakukan oleh badan peradilan yang menangani kasus pelanggaran lalu lintas di jalan raya.

2.Faktor factor yang menjadi pertim bangan Hakim dalam menerapkan Pasal 310 UU Nomor 22 Tahun 2009 terhadap pengem udi yang menyebabkan ora ng lain luka berat di PengadilanNegeriBata $\mathrm{m}$.

Menurut Undang- Undang Nomor 48 Tahun 2009 Tentang Kekuasaan Kehakiman, Pertimbangan Hakim adalah pemikiran- pemikiran atau pendapat Hakim dalam menjatuhkan putusan dengan melihat hal- hal yang dapat meringankan atau memberatkan pelaku. Setiap Hakim wajib menyampaikan pertimbangan atau pendapat tertulis terhadap perkara yang sedang diperiksa dan menjadi bagian yang tidak terpisahkan dari putusan.

\section{KESIMPULAN}

Berdasarkan hasil wa wancara Penulis dengan Hakim Pengadilan Negeri Bata m, yaitu bapak JAROT WIDIYATMONO, SH, selaku Ketua Majelis,terdapat hal-hal yang menjadi pertimbangan hakim yaitu hal- hal yang meringankan dan memberatkan Terdak wayaitu:

1. Faktor-faktor yang meringankan hukuman yaitu:

a. Terdak wa belum pernah dihukum. Belum pernah dihukumnya seorang terdak wa, hal ini membuktikan bahwa terdakwa bukan merupakan seorang penjahat kambuhan atau residivice. Hal ini jelas merupakan salah satu factor yang meringankan hukuman. 
b. Terdak wa mengakui secara terus terang perbuatannya. Adanya suatu pengakuan dari Terdak wa yang secara terus terang terhadap perbuatan yang dilakukan, khususnya dalam kasus kecelakaan lalu lintas dapat membuat pemeriksaan dipersidangan dapat berjalan dengan lancar.

c. Terdak wa bersikap sopan dalam persidangan. Sikap sopan yang diperlihatkan oleh terdak wa kepada majelis hakim dalam persidangan membuktikan bahwa Terdak wa menghormati proses pengadilan, sehingga akan timbul suatu tanggapan yang positif dari majelis Hakim terhadap Terdak wa, yang tentunya dapat meringankan Terdak wa dari hukuman.

d. Terdak wa menyesali perbuatannya. Adanya suatu penyesalan yang diwujudkan dalam suatu pengakuan dari Terdakwa, hal ini membuktikan bahwa Terdak wa benar-benar menyadari kesalahannya dan tidak akan mengulangi lagi perbuatannya.

e. Terdak wa mempunyai tanggungan keluarga Apabila Terdakwa mempunyai tanggungan keluarga tentunya terdak wa merupakan tulang punggung dari keluarganya, yang apabila Terdakwa ditahan dalam waktu yang cukup lama, maka dikhawatirkan keluarganya akan terlunta-lunta, hal inilah yang menjadi salah satu faktor meringankan Terdakwadari hukuman.

f. Terdak wa sebagai satu-satunya sumber kehidupan keluarga Apabila Terdak wa ditahan dalam waktu yang cukup lama maka dikhawatirkan keluarga terdak wa akan kesulitan. Maka hal ini juga menjadi salah satu factor meringankan hukuman.

g. Usia Terdak wa masih muda. Usia Terdak wa yang masih muda menjadi pertimbangan hakim dalam menjatuhkan pidana penjara, hal ini untuk memberikan kesempatan kepada terdakwa agar jangan sampai cita-cita dan masa depannya tidak tercapai, usia muda juga merupakan salah satu generasi penerus bangsa yang diharapkan dapat berhasil.

h. Terdak wa telah lanjut Us ia. Us ia yang terlalu lanjut bagi seorang Terdak wa menjadi pertimbangan hakim, karena hakim memberikan kesempatan kepada Terdak wa untuk menikmati hari tuanya dengan baik, tidak dengan pesakitan. Selain itu usia terlalu lanjut dikha watirkan tidak dapat bertahan dalam menjalankan masa hukumannya.

i. Adanya Perdamaian antara Terdakwa dengan keluarga Korban. Suatu Perdamaian yang dilakukan oleh Terdak wa yaitu dengan memberikan bantuan, santunan ataupun membayarkan seluruh biaya-biaya yang telah dikeluarkan korban, 
tentunya akan mengurangi dan mengobati kepedihan hati keluarga korban, yang dapat memberikan maaf kepada Terdakwa mejadi salah-satu factor meringankan hukuman.

j. Terdak wa juga mengalami cacat dan luka fisik, Apabila Terdakwa juga mengalami cacat dan luka fisik sehingga menurut penilaian Hakim, bahwa sebelum pidana dijatuhkan tentunya Terdakwa juga sudah merasakan suatu penderitaan fis ik yang dirasakan sangat berat dan memukul jiwanya.

k. Kesalahan Terdak wa dinilai bukan unsur kesengajaan melainkan unsur kealpaan unsur kealpaan merupakan suatu perbuatan yang tidak dikehendaki oleh batin si terdak wa, hal ini berbeda dengan unsur kesengajaan yang mempunyai 2 unsur yaitu mengetahui dan menghendaki, tentunya unsur kealpaan ini merupakan salah satu faktor meringankan hukuman yang menjadi pertimbangan hakim dalam menjatuhkan suatu putusan pidana terhadap seorang Terdak wa.

2. Faktor-faktor yang memberatkan hukuman yaitu :

a. Terdak wa sudah pernah dipidana dalam kasus yang sama merupakan suatu pertimbangan hakim, bahwa selama ini terdakwa tidak mau bertobat dan menyesalinya dengan sungguh-sungguh, bahkan mengulangi kejahatan yang telah diperbuatnya sama seperti seorang Residivice. Seorang recidive dapat dikatakan tidak "kapok" meskipun sudah dijatuhi hukuman, maka ternyata ancaman maksimum hukuman kurang berat bagi pelakunya. Hal residive ini diatur dalam titel XXXI Buku II KUHP, dan biasanya terbatas pada tenggang waktu lima tahun setelah hukuman pidana selesai dijalankan.

b. Terdakwa memberikan keterangan yang berbelit-belit sehingga menyulitkan jalannya pemeriksaan Sulitnya pemeriksaan dipersidangan akan membuat penilaian hakim bahwa terdakwa plint-plant atau berubah-ubah, sehingga persidangan menjadi lebih lama dan membutuhkan biaya yang cukup besar yang harus dikeluarkan.

c. Terdak wa berlaku tidak sopan dalam persidangan. Terdak wa yang berlaku tidak 
sopan dalam persidangan bagi hakim merupakan suatu bentuk tidak menghormati

Hukum dan pengadilan sehingga menjadi salah satu faktor yang memberatkan

hukuman bagi si terdakwa itu sendiri. 
d. Terdak wa tidak menyesali perbuatannya Merupakan suatu bentuk bahwa apa yang telah diperbuat oleh terdak wa seakan akan sudah takdirnya si terdak wa, 
yang tidak perlu disesalinya. Hal ini menandakan terdak wa mungkin saja suatu hari nanti akan mengulangi perbuatannya tadi.

e. Terdak wa melarikan diri. Hal ini melambangkan bahwa Terdakwa tidak mau bertanggung ja wab terhadap kesalahan yang dilakukannya, sehingga menyulitkan penegak Hukum dalam mencari suatu kebenaran dan mengeluarkan banyak uang negara untuk dapat menangkap si pelaku. Tentunya hal ini menjadi faktor yang memberatkan hukuman.

f. Terdak wa tidak menolong korban. Membuktikan bahwa terdakwa tidak memiliki rasa prikemanusiaan terhadap sesama dan tanggung jawab, hal ini bertentangan Pancasila, khususnya dengan sila ke-dua, sehingga dapat menimbulkan keresahan dalam masyarakat apabila si terdakwa dihukum ringan. Hal inilah yang menjadi faktor memberatkan hukuman.

g. Terdak wa tidak memiliki SIM yang sah dan sesuai peruntukkannya Unsur tidak memiliki SIM yang sah dan sesuai peruntukkannya menjadi pertimbangan hakim, karena unsur ini dianggap bahwa si terdak wa tahu dan mengetahui kesalahan yang diperbuat, dan disini bagi hakim ada unsur kesengajaan untuk tindak pidana pelanggaran yang mengakibatkan terjadinya kecelakaan lalu-lintas di jalan raya. Dalam hal ini perbuatan terdakwa sangat bertentangan dengan ketentuan Pasal 18 UU No.14 tahun 1992 tentang Lalu lintas dan angkutan jalan, yang mengatur tentang ke wajiban Pengemudikan kendaraan bermotor memiliki SIM yang sesuai dengan golongannya.

h. Terdak wa tidak meminta maaf kepada keluarga korban. Tidak adanya permintaan maaf dari terdak wa kepada keluarga korban, tentunya keluarga korban tidak memaafkan, dan hal ini membuktikan keegoisan terdak wa, sehingga menjad i faktor yang memberatkan hukuman.

i. Belum adanya Bantuan dari Terdak wa kepada keluarga korban, apabila terdak wa belum atau tidak memberikan bantuan kepada keluarga korban, tentunya keluarga korban secara materiil sangat dirugikan dan tidak terbantu sehingga hakim menilai hal ini sangat memberatkan keluarga korban dan menjadi faktor yang memberatkan hukuman bagi si terdakwa. 
j. Terdak wa mengemudi dalam keadaan mabuk. Terdak wa mengemudi dalam

keadaan mabuk, hal ini menjadi semakin memberatkan karena kondisi pikiran 
pengemudi yang mabuk tentunya akan mempengaruhi konsentrasi saat mengemudikan kendaraannya yang dapat berakibat fatal / kecelakaan lalu- 
lintas, keadaan mabuk merupakan suatu keadaan yang sengaja dibuat oleh sipelaku sendiri yang membuat dirinya tidak sadar sepenuhnya, yang dilakukan dengan meminum minuman keras, minum obat-obatan terlarang dengan sengaja sehingga hal ini menjadi faktor utama terjadinya kecelakaan lalu lintas jalan raya.

Menurut Prodjodikoro (2002; 90 bahwa meskipun dalam teori berdasarkan atas Pasal 44 ayat 1 KUHP seseorang yang mabuk itu dapat lolos dari hukuman, namun menurutnya amat kecil kemungkinan seorang yang mabuk sampai sangat kurang berdaya memahami kegawatan akibat perbuatannya, apabila seorang di dalam keadaan mabuk mengendarai kendaraan sehingga menabrak orang sampai terluka berat, maka orang itu sepantasnya malahan harus dikenakan hukuman lebih berat dari seorang yang tidak mabuk.

\section{DAFTAR PUSTAKA}

Ramdlon Naning, Menggarahkan Kesadaran Masyarakat dan Disiplin Penegak Hukum Dalam Lalu Lintas, Bina Ilmu, Surabaya, 1983.

Hardiman,GerakanDisiplinNasionalDalamBerlalu-lintasSejakDini, AsosiasiKeselamatanJalanIndonesia, Jakarta,1998.

RobertPaladeng,dkk,Undang-undangLalu lintasdanAngkutanJalanAnekaPandangandanOpini,Jakarta: PustakaSinarHarapan,1993.

Sjachran Basah,Eksistensi dan Tolak Ukur Badan Peradilan Administrasi Di Indonesia, Bandung: Alumni, 1997.

Mochtar Kusumaatmadja,Pembinaan Hukum Dalam Rangka Pembaangunan Nasional, Jakarta: PT,Alumni, 2006.

Bambang Poernomo,Asas-Asas Hukum Pidana,Jakarta:Ghalia Indonesia,1993

Moeljatno,KUHP Dan KUHAP,Jakarta:Bumi Aksara,2000.

W.J.S Poerwadarmita, Kamus Umum Bahasa Indonesia, Balai Pustaka, Jakarta, 1996

H.S. Djajusman, Polisi Dan Lalu Lintas, Mabak, Bandung, 1976.

WirjonoProdjodikoro,Buku II KUHP,Bandung,2002.

Undang-Undang NRI Tahun 1945.

Undang-Undang No 22 Tahun 2009. 
Awaloedin Jamin, disampaikan dalam seminar tentang "Kesadaran dan Tata Tertib Hukum Masyarakat Dalam Masalah Lalu Lintas Jalan Raya ", yang diselenggarakan oleh Lembaga Riset dan Pengabdian Masyarakat Fakultas Hukum Universitas Islam Indonesia, tanggal 16-19 Maret 1981 di Kaliurang Yogyakarta 